УДК 342.721

DOI https://doi.org/10.32849/2663-5313/2020.3.33

Людмила Приполова,

канд. юрид. наук,

старший науковий співробітник науково-дослідного відділу

проблем військового законодавства

Центтру воєнно-стратегічних досліджень

Національного університету оборони України імені Івана Черняховського

\title{
ПРАВОВИЙ СТАТУС ОСІБ, ЗНИКЛИХ БЕЗВІСТИ У ЗВ'ЯЗКУ ЗІ ЗБРОЙНИМ КОНФЛІКТОМ ТА ЗА ОСОБЛИВИХ ОБСТАВИН
}

Розглянуто особливості нормативно-правового регулювання визначення понять «особа, зникла безвісти у зв'язку зі збройним конфліктом» та «особа, зникла безвісти за особливих обставин», які містяться в Законі України «Про правовий статус осіб, зниклих безвісти». Зауважено, що особлива нагальність проблеми розшуку осіб, які безвісти зникли в межах зони конфліктної ситуацій, підтверджується змістом Річної начіональної програми під егідою Комісії Україна - НАТО на 2019 рік, затвердженої Указом Президента.

Проаналізовано сутність зазначених понять та виокремлено недоліки нормативного регулювання їх визначення, а саме: огляд змісту наведених понять демонструє певну їх тотожність; перераховані обставини зникнення є досить схожими; у визначенні особи, зниклої безвісти у зв'язку зі збройним конфліктом, зазначена обставина - зона збройного конфлікту, нормативне визначення якої відсутнє в «оборонних законах» та основних стратегічних документах України; в дефініції поняття «особа зникла безвісти за особливих обставин» законодавеиь задекларував більш широкий та конкретизований перелік обставин, на відміну від тих, які перераховані у визначенні поняття «особа, зникла безвісти у зв'язку зі збройним конфліктом». Підсумовано, що поняття «особа, зникла безвісти у зв'язку зі збройним конфліктом» за своїм смисловим навантаженням є вужчм і охоплюється поняттям «особа, зникла безвісти за особливих обставин». Короткий огляд змісту Закону Украйни «Про правовий статус осіб, зниклих безвісти» показує наявність низки проблемних питань, що потребують вирішення. У контексті проблематики статті розглянуто співвідношення вищезазначених понять із поняттям «особа безвісно відсутня», яке міститься в Цивільному кодексі України. Проведено огляд науково-теоретичних поглядів низки вчених із зазначеної проблематики.

Окремо зазначено роль Міжнародного Комітету Червоного Хреста (МКЧХ) у пошуку таких категорій осіб. Згадано і про такі структури МКЧХ, як Центральне довідкове агентство у справах військовополонених і Центральне довідкове агентство у справах осіб, які перебувають під захистом.

Ключові слова: обставини зникнення особи, особи, які зникли безвісти, особа безвісно відсутня, Міжнародний Комітет Червоного Хреста, правовий статус осіб, зниклих безвісти.

Постановка проблеми. Проблематика захисту прав людини та їі свобод - одна 3 найбільш досліджених та запитуваних в осередку юридичної науки. Тоді як повсякчас виникаючі загрозливі ситуації у світовій безпеці та на території України зокрема диктують необхідність пошуку нового алгоритму захисту порушених прав людини. Оскільки в Україні актуалізувалось питання створення ефективної системи забезпечення реалізації основних прав і свобод людини під час збройної агресії Росії на Донбасі, незаконної окупації Автономної Республіки Крим та міста Севастополя, це питання стало одним з пріоритетних і його вирішення здій- снюється на найвищому державному рівні. Тому на реалізацію ч. 4 ст. 6 Закону України «Про особливості державної політики iз забезпечення державного суверенітету України на тимчасово окупованих територіях у Донецькій та Луганській областях» було розроблено проєкт Постанови Кабінету Міністрів України «Про затвердження Положення про порядок ведення Реєстру фактів порушень прав і свобод людини і громадянина у зв'язку з тимчасовою окупацією частини території України». Цей проєкт обговорювався на засіданні Робочої групи з питань захисту жертв збройних конфліктів Міжвідомчої комісії з питань застосування 
та реалізації норм міжнародного гуманітарного права в Україні (травень 2019 року). Підтвердженням актуальності зазначеного питання є проведення 31 січня 2020 року в Офісі Президента України засідання робочої групи з питань зниклих безвісти на Донбасі та військових і цивільних заручників (полонених) [1]. Зокрема, обговорювалась необхідність розробки та відпрацювання правового механізму допомоги з боку держави вищезазначеній категорії осіб. Так, нині юридичну експертизу проходить проєкт Закону «Про соціальний і правовий захист осіб, позбавлених свободи внаслідок збройної агресії проти України».

Серед невідкладних питань у сфері захисту прав і свобод людини є питання розшуку осіб, які безвісти зникли в межах зони конфліктної ситуації. Така нагальність підтверджується змістом Річної національної програми під егідою Комісії Україна - НАТО на 2019 рік, затвердженої Указом Президента України № 117/2019 від 10.04.2019 року [2]. А саме у названій програмі серед пріоритетних завдань цілі 1.3.5. «Ефективна система надання правової допомоги» $є$ забезпечення захисту прав та законних інтересів осіб, які були позбавлені особистої свободи внаслідок дій незаконних збройних формувань Російської Федерації та окупаційної адміністрації Російської Федерації на тимчасово окупованих територіях у Донецькій та Луганській областях, а також підтримка зазначених осіб та членів їхніх сімей. Слід зазначити, що відповідно до офіційної інформації [3] Уряд нещодавно схвалив Річну національну програму під егідою Комісії Україна - НАТО на 2020 рік. Саме у цьому документі вперше зосереджено увагу на правах, свободах та законних інтересах людини. Офіційні дані Антитерористичного центру Служби безпеки України за 2019 рік свідчать про значну кількість осіб, які були незаконно позбавлені волі і зрештою звільнені починаючи з квітня 2014 року (більше трьох тисяч осіб). Інформація правозахисних організацій щодо кількості осіб, які зникли безвісти на території Донецької та Луганської областей з 2014 року і дотепер, є неоднозначною, кількість таких осіб, за різними даними, сягає близько чотирьох тисяч.

Аналіз останніх досліджень. В Україні була проведена значна кількість наукових досліджень та опубліковано наукові праці, які стосуються особливостей реалізації прав людини і громадянина, їх захисту тощо. Зокрема, над проблематикою правового статусу особи, зниклої безвісти, працювали такі вчені: Д. Бойчук, В. Гожій-Демиденко, О. Зайчук, В. Журавський, О. Іляшко, Н. Камін- ська, А. Кличкова, І. Колошко, О. Мазурок, М. Перепелиця, Л. Фесечко та інші. Водночас дослідження проблемних питань правового статусу осіб, зниклих безвісти під час збройних конфліктів, лишається перспективним і нагальним як для юридичної науки, так і для нормативно-правової бази України з огляду на потребу їх оптимізації.

Оскільки виникла потреба у нормативному закріпленні визначення поняття «особи, що зникли безвісти в межах зони конфліктної ситуації» і загалом удосконалення нормативно-правового регулювання їх статусу, 12 липня 2018 року був прийнятий Закон України «Про правовий статус осіб, зниклих безвісти», який, на думку низки науковців, потребує певного удосконалення. Зазначене виявляється неможливим без науково-теоретичного обгрунтування, що і впливає на формування цілі статті, а саме науково-теоретичного огляду визначень основних понять Закону України «Про правовий статус осіб, зниклих безвісти».

Виклад основного матеріалу. У згаданому Законі в ст. 1 [4] визначено низку понять, зокрема і «особа, зникла безвісти», «особа, зникла безвісти у зв’язку зі збройним конфліктом», «особа, зникла безвісти за особливих обставин». Так, «особа, зникла безвісти» - це фізична особа, стосовно якої немає відомостей проїї місцеперебування на момент подання заявником заяви про іï розшук. Виходячи із вищезазначеного, доцільним видається здійснити аналіз сутності останніх двох понять. Так, особа, зникла безвісти у зв'язку зі збройним конфліктом, визначена як особа, яка зникла безвісти в зоні збройного конфлікту під час проходження нею військової служби або за будь-яких інших обставин, що підтверджують факт перебування особи у цій зоні. Відповідно, особа, зникла безвісти за особливих обставин, - це особа, зникла безвісти у зв'язку зі збройним конфліктом, воєнними діями, заворушеннями всередині держави або у зв'язку з надзвичайними ситуаціями природного чи техногенного характеру або іншими подіями, що можуть спричинити масову загибель людей. Огляд змісту наведених понять демонструє певну їх тотожність. Так, перераховані обставини зникнення є досить схожими, але перелік у другому є більш деталізованим. Водночас змість наведених понять відкриває низку дискусійних питань. А саме у визначенні особи, зниклої безвісти у зв'язку зі збройним конфліктом, зазначена обставина - зона збройного конфлікту, нормативно-правове визначення якої відсутнє в «оборонних законах» та основних стратегічних документах України. Саме поняття «збройний конфлікт» 
разом 3 поняттям «воєнний конфлікт» відносно нещодавно були визначені у Законі України «Про національну безпеку України» (ст. 1) [5], водночас посилання відсутнє в Законі України «Про правовий статус осіб, зниклих безвісти» у згадці в ст. 1 щодо тлумачення терміна «збройний конфлікт». Загалом, надане законодавцем визначення понять «воєнний конфлікт» та «збройний конфлікт» за своїм змістом є доволі близьким, при цьому воєнний конфлікт є більш широким поняттям ніж збройний конфлікт. Дефініція збройного конфлікту відрізняється більш деталізованим колом суб'єктів. Таким, що потребує уточнення в перспективі, лишається перелік варіантів можливих ворогуючих сторін у визначенні поняття «збройний конфлікт». Водночас перспективним для наукової дискусії лишається питання щодо необхідності законодавчого визначення поняття «війна» як виду воєнного конфлікту. Характеристика представленого визначення поняття «особа, зникла безвісти у зв'язку зі збройним конфліктом» показує те, що законодавець чітко відмежував умови, місце й категорію такої особи, визначивши їх як «під час проходження нею військової служби або за будь-яких інших обставин, що підтверджують факт перебування особи у цій зоні». Водночас під час визначення поняття «особа, зникла безвісти у зв'язку зі збройним конфліктом» законодавець передбачає наявність будь-яких інших обставин, що підтверджують факт перебування особи у цій зоні під час проходження нею військової служби. Тому дещо дискусійним видається саме такий узагальнений виклад «інших обставин» без їх конкретного перерахування, що було б доцільніше для уникнення надалі ситуацій із трактуванням такого визначення. Тоді як у дефініції поняття «особа, зникла безвісти за особливих обставин» законодавець задекларував більш широкий та конкретизований перелік обставин, на відміну від тих, які перераховані у визначенні поняття «особа, зникла безвісти у зв'язку зі збройтим конфліктом». Загалом, можемо підсумувати, що поняття «особа, зникла безвісти у зв'язку зі збройним конфліктом» за своїм смисловим навантаженням $€$ вужчим і за великим рахунком охоплюється поняттям «особа, зникла безвісти за особливих обставин».

Слід звернути увагу на те, що чинний Цивільний кодекс України оперує поняттям «особа безвісно відсутня». У ст. 43 встановлено, що фізична особа може бути визнана судом безвісно відсутньою, якщо протягом одного року в місці її постійного проживання немає відомостей про місце її перебування [6]. Отже, зміст поняття «особа безвісно від- сутня» Цивільного кодексу України відрізняється від змісту вищенаведеного поняття «особа, зникла безвісти» в Законі України «Про правовий статус осіб, зниклих безвісти» не лише назвою, а і процедурою визнання особи як такої. Така ситуація може призвести до підміни понять, чим у черговий раз підтверджується актуальність подальшого науково-теоретичного дослідження проблеми із перспективою вдосконалення відповідного нормативно-правового регулювання.

Продовжуючи аналіз змісту вищезазначених понять, слід звернути увагу і на те, що в ст. 9 Закону України «Про правовий статус осіб, зниклих безвісти» виокремлено особливості правового статусу осіб, які уповноважені виконувати функції держави. Так, ч. 1 ст. 9 говорить про те, що за особою, уповноваженою на виконання функцій держави, яка зникла безвісти під час збройного конфлікту, воєнних дій, заворушень всередині держави або у зв'язку з виконанням службових обов'язків 3 ліквідації наслідків надзвичайних ситуацій природного чи техногенного характеру, зберігаються місце роботи, займана посада та середній заробіток на підприємстві, в установі, організації, незалежно від підпорядкування, але не більш як до моменту оголошення такої особи померлою у порядку, встановленому законодавством [4]. Слід відзначити, що у визначенні поняття «особа, зникла безвісти у зв'язку зі збройним конфліктом» та «особа, зникла безвісти за особливих обставин» не згадуються такі категорії осіб. Водночас ч. 2 ст. 9 є відсильною щодо гарантій, передбачених Законом України «Про соціальний і правовий захист військовослужбовців та членів їхніх сімей» для осіб, які зникли безвісти під час проходження військової служби внаслідок збройного конфлікту та/або воєнних дій. Інакше кажучи, ч. 2 ст. 9 лишає відкритим питання про те, стосовно якої категорії особи, зниклої безвісти, стосується iï зміст, виходячи iз визначень, зафіксованих у ст. 1 цього ж Закону (зниклої безвісти у зв'язку зі збройним конфліктом чи за особливих обставин).

Дещо критично оцінюють Закон України «Про правовий статус осіб, зниклих безвісти» і Д. Бойчук та М. Перепелиця, які у своїй науковій статті виокремлюють такі недоліки: чітко не враховано всі обставини, за яких можуть особи зникнути безвісти; не уточнено терміни подання заяви про зникнення особи безвісти; не вказано, протягом якого строку не має бути відомостей про місцеперебування особи; Єдиний реєстр осіб, зниклих безвісти за особливих обставин, натепер не є загальнодоступним $[7$, c. 115,117$]$. 
У контексті досліджуваної тематики слід звернути увагу на деякі положення Інструкції про порядок виконання норм міжнародного гуманітарного права у Збройних силах України, затвердженої Наказом Міністерства оборони України № 164 від 23 березня 2017 року [8]. Так, п. 19 частини $2 \ll$ Основні терміни і поняття міжнародного гуманітарного права» жертвами збройного конфлікту визначає: поранених хворих; осіб, які потерпіли корабельну аварію (аварію літального апарата); осіб, зниклих безвісти; загиблих (померлих); військовополонених або інших осіб, свобода яких обмежена у зв'язку зі збройним конфліктом; цивільних осіб, які знаходяться в районі воєнних дій та на окупованій території. У п. 44 Інструкції надано визначення осіб, зниклих безвісти. А саме, що це особи, які зникли під час ведення воєнних дій і місцезнаходження яких невідоме. Слід також зазначити, що пропоновані в Інструкції визначення понять базуються на низці нормативно-правових актів у сфері міжнародного гуманітарного права, ратифікованих Україною. Зміст поняття «особи, зниклі безвісти» показує суттєву відмінність такого ж поняття в Законі України «Про правовий статус осіб, зниклих безвісти».

Для комплексного огляду зазначеної проблематики, окрім нормативно-правового аспекту, доцільним буде здійснення i науково-теоретичного огляду. Так, одним 3 небагатьох дослідників вищенаведеної проблематики є Л. Фесечко. Автор у дослідженні особливостей пошуку осіб, зниклих безвісти внаслідок збройного конфлікту, звертався до такого визначення поняття «особи, зниклі безвісти»: це особи, чиї сім'ї не мають відомостей про них після їх зникнення під час збройного конфлікту або ситуації насильства всередині країни. Як зауважує автор, це цілком офіційне визначення не відображає відчаю сімей, які шукають інформацію про місцезнаходження рідних, не знають, живі вони або померли, і не можуть забути жахливі події, що зруйнували їхнє життя [9, с. 402]. Як підсумок зазначено, що державам необхідно вживати всіх законодавчих, регулятивних і практичних заходів з метою виконання зобов'язань відповідно до міжнародного права, включаючи зобов'язання, що стосуються з'ясування долі осіб, зниклих безвісти. Крім того, держави мають у кримінальному законодавстві передбачати кримінальні покарання за незаконне приховування наявних відомостей або за відмову вжити заходів щодо отримання або надання відомостей про факт і причину смерті, коли такі відомості запрошуються родичем особи, зниклої безвісти [10, с. 409].
О. Іляшко у дослідженні питання щодо громадянських і політичних прав та свобод людини на тимчасово окупованих територіях зазначав, що в Україні актуалізувалась потреба у створенні системи ефективних способів забезпечення, гарантій захисту прав і свобод людини на тимчасово окупованих територіях [10, с. 19]. Автор зауважував, що ситуація з порушенням чи обмеженням конституційних громадянських і політичних прав та свобод людини на тимчасово окупованих територіях України демонструє необхідність приділення уваги окремим категоріям - внутрішньо переміщеним особам, дітям, пенсіонерам, військовослужбовцям, учасникам ATO/OOC тощо. Їхній статус має бути не лише належним чином урегульований на законодавчому рівні, а і забезпечений реальними дієвими механізмами реалізації [10, с. 25].

Слід зазначити, що велику роль у пошуку таких категорій осіб відіграє Міжнародний Комітет Червоного Хреста (далі - МКЧХ). Так, консультаційна служба з міжнародного гуманітарного права у своєму аналітичному матеріалі підсумувала, що у ситуаціях збройних конфліктів МКЧХ має отримувати доступ до всіх осіб, які позбавлені волі у зв'язку з конфліктом (згідно з Женевськими конвенціями). Також МКЧХ доручено організацію та забезпечення роботи Центрального довідкового агентства у справах військовополонених і Центрального довідкового агентства у справах осіб, які перебувають під захистом. Ці агентства відповідають за збір і передачу всієї наявної інформації про військовополонених та інші уразливі групи осіб, як-то діти [11]. Слід зазначити, що саме Женевськими конвенціями [12] передбачено створення Довідкових бюро для забезпечення централізованого збору інформації про військовополонених і цивільних осіб, які належать до країни супротивника, передавання такої інформації стороні, проведення розслідування з метою з'ясування місця знаходження осіб, зниклих безвісти.

\section{Висновки}

Короткий огляд змісту Закону України «Про правовий статус осіб, зниклих безвісти» у контексті сутності вищерозглянутих дефініцій актуалізує потребу доопрацювання окремих норм цього Закону. Нагадаємо, що така необхідність продиктована тим, що поняття «особа, зникла безвісти у зв'язку зі збройним конфліктом» $є$ вужчим і більшою мірою охоплюється поняттям «особа, зникла безвісти за особливих обставин»; у понятті «особа, зникла безвісти у зв'язку зі збройним конфліктом» не досить 
конкретизований перелік умов та обставин зникнення; у визначенні особи, зниклої безвісти у зв'язку зі збройним конфліктом, зазначена обставина - зона збройного конфлікту, нормативне визначення якої відсутнє; терміни подання заяви про зникнення особи безвісти не уточнено; Єдиний реєстр осіб, зниклих безвісти за особливих обставин, натепер не $€$ загальнодоступним тощо. Викладене вище вчергове підтверджує надтерміновість вирішення питань, пов'язаних із врегулюванням правового статусу особи, зниклої безвісти у зв'язку зі збройним конфліктом, та особи, зниклої безвісти за особливих обставин, шляхом проведення подальших науково-теоретичних досліджень та удосконалення відповідних нормативно-правових актів.

\section{Список використаних джерел:}

1. В Офісі Президента обговорили створення Комісії з розшуку зниклих безвісти. URL: htth:// www.president.gov.ua/news/v-ofisi-presidenta-obgovorili-stvorennya-komisiyi-z-rozshuku-59513.

2. Річна національна програма під егідою Комісії Україна - НАТО на 2019 рік, затверджена Указом Президента України від 10 квітня 2019 року № 117/2019. URL: http:// zakon.rada.gov.ua/laws/show/117/2019.

3. Уряд схвалив Річну національну програму під егідою Комісії Україна - НАТО на 2020 рік. URL: https://www.mil.gov.ua/ news/2020/02/05/uryad-shvaliv-richnu-naczionalnu-programu-ukraina-nato-novoi-yakosti/.

4. Про правовий статус осіб, зниклих безвісти : Закон України від 12 липня 2018 року
№ 2505-VIII. URL: https://zakon.rada.gov.ua/ laws/show/2505-19.

5. Про національну безпеку України : Закон України від 21 червня 2018 року № 2469-VIII. URL: http://zakon.rada.gov.ua/laws/show/2469-19.

6. Цивільний кодекс України : Закон України від 16 січня 2003 року № 435-IV. URL https://zakon.rada.gov.ua/laws/show/435-15.

7. Перепелиця М., Бойчук Д. Особливості набуття правового статусу особи, зниклої безвісти. Актуальні проблеми правознавства. 2019. Вип 3 (19). С. 113-120.

8. Інструкція про порядок виконання норм міжнародного гуманітарного права у Збройних силах України, затверджена Наказом Міністерства оборони України № 164 від 23 березня 2017 року. URL: https://zakon.rada.gov.ua/laws/ show/z0704-17.

9. Фесечко Л. І. Пошук осіб, зниклих безвісти внаслідок збройного конфлікту. Актуальні проблеми політики. 2009. Вип. 37. С. 401-410. URL: http://dspace.onua.edu.ua/handle/11300/325.

10. Іляшко О.О.Порушення громадянських і політичних прав та свобод людини на тимчасово окупованих територіях України та способи їх захисту. Вчені записки ТНУ імені В. І. Вернадського. Серія «Юридичні науки». 2018. Том 29 (68) № 4. C. $19-27$.

11. Зниклі безвісти та їхні сім'ї. Консультаиійна служба з міжнародного гуманітарного права МКЧХ. 2015. № 12. URL: http://ua.icrc.org/ wp-content/uploads/sites/98/2018/09/Missing_ families Ukr-1.pdf

12. Женевские конвенции от 12 августа 1949 года и Дополнительные протоколы к ним. 3-е изд., испр. Москва, 2003. 344 с.

The specificities of the legal regulation of the definition of the concepts of missing persons in connection with armed conflict and missing persons in the special circumstances contained in the Law of Ukraine "On the Legal Status of Missing Persons" are considered. It is noted that the special urgency of the search for missing persons within the conflict zone is confirmed by the content of the Annual National Program under the auspices of the Ukrainian Commission - NATO for 2019, approved by the Presidential Decree.

The essence of these concepts is analyzed and the shortcomings of the normative regulation of their definition are highlighted, namely: review of the contents of the given concepts, demonstrates their certain identity; the listed circumstances of disappearance are quite similar; the identification of a missing person in connection with an armed conflict is indicated by a circumstance - a zone of armed conflict, the regulatory definition of which is absent in the "defense lawe" and the main strategic documents of Ukraine; in defining the concept of "missing person in special circumstances", the legislator has declared a broader and more specific list of circumstances, unlike those listed in the definition of "missing person in connection with armed conflict". It is summarized that the concept of "missing person in connection with armed conflict" by its semantic load is narrower and is covered by the concept of "missing person in special circumstances". A brief overview of the content of the Law of Ukraine "On the Legal Status of Missing Persons" reveals a number of problematic issues that need to be resolved. In the context of the article's issues, the relation of the above-mentioned concepts with the term "missing person" is contained in the Civil Code of Ukraine. A review of the scientific-theoretical views of a number of scientists on the outlined issues is conducted.

The role of the International Committee of the Red Cross (ICRC) in the search for such categories of persons is separately noted. The role of ICRC structures, such as the Central reference service for prisoners of war and the Centre referral service for protected persons, is mentioned separately.

Key words: circumstances of the person's disappearance, disappeared person, missing person, International Committee of the Red Cross, legal status of a person who has disappeared. 